Chicago-Kent College of Law

Scholarly Commons @ IIT Chicago-Kent College of Law

February 2004

\title{
A Bridge Too Far: The Fall of the Fifth WTO Ministerial Conference in Cancún and the Future of Trade Constitution
}

Sungjoon Cho

IIT Chicago-Kent College of Law, scho1@kentlaw.iit.edu

Follow this and additional works at: https://scholarship.kentlaw.iit.edu/fac_schol

Part of the International Trade Law Commons

\section{Recommended Citation}

Sungjoon Cho, A Bridge Too Far: The Fall of the Fifth WTO Ministerial Conference in Cancún and the Future of Trade Constitution, 7 J. Int'l Econ. L. 219 (2004).

Available at: https://scholarship.kentlaw.iit.edu/fac_schol/160

This Article is brought to you for free and open access by the Faculty Scholarship at Scholarly Commons @ IIT Chicago-Kent College of Law. It has been accepted for inclusion in All Faculty Scholarship by an authorized administrator of Scholarly Commons @ IIT Chicago-Kent College of Law. For more information, please contact jwenger@kentlaw.iit.edu, ebarney@kentlaw.iit.edu. 


\title{
A BRIDGE TOO FAR: THE FALL OF THE FIFTH WTO MINISTERIAL CONFERENCE IN CANCÚN AND THE FUTURE OF TRADE CONSTITUTION
}

\section{Sungjoon Cho ${ }^{\star}$}

'Poverty anywhere constitutes a danger to prosperity everywhere'. ${ }^{\star \star}$

\begin{abstract}
This article is intended to contribute to the process of diagnosis and prescription in response to the fiasco of the Fifth WTO Ministerial Conference in Cancún, Mexico, in September 2003. The article sketches previous WTO Ministerial Conferences in an attempt to glimpse the root of the problems that eventually caused the collapse of the Cancún Conference. It then focuses on the main developments in Cancún and offers a 'postmortem', not in an attempt to place blame but to better understand what went wrong. It observes that North-South tension is likely to continue for the time being while rich countries, especially the US, will lean toward bilateralism and regionalism. Yet, it also suggests that with a combination of hard work by Member countries, political support from NGOs and businesses, and the Secretariat's constructive role, the Doha Round can and should be saved. The article concludes that the global trading community is now embracing another 'constitutional moment' which parallels the creation of the GATT 1947 and the WTO.
\end{abstract}

\section{INTRODUCTION}

The fanfare of the Fifth WTO Ministerial Conference in Cancún, Mexico, in September 2003 quickly developed into an inglorious din of cross-criticism and finger-pointing. The Cancún Conference was expected to deliver a solid, workable framework to fulfil the Doha Development Agenda (DDA) and to herald a positive signal to the global trading community. Despite hopes and

\footnotetext{
* Assistant Professor of Law, Chicago-Kent College of Law, Illinois Institute of Technology, 565 West Adams St., Chicago, IL 60661-3691, USA. I thank Professor John H. Jackson for his encouragement to write this piece. I also extend my gratitude to two anonymous commentators for their valuable feedback and to Ms Isabelle Van Damme for her administrative and editorial assistance. All errors are mine.

$\star \star$ The Constitution of the International Labor Organization, Annex (Declaration Concerning the Aims and Purposes of the International Labor Organization), para I (c), http://www.ilo.org/public/ english/about/iloconst.htm\#annex.
} 
ambition, the Cancún Conference collapsed, failing to address developed countries' prevailing protectionism in the sectors of agriculture and textiles, on which many developing countries depend for their subsistence. The collapse has begun to arouse doubts and skepticism about the effectiveness of the multilateral trading system.

Although the failure of the Cancún Conference is a source of disappointment and even frustration, the global trading community cannot afford any inaction or apathy at a time when millions on earth are still suffering from hunger and poverty, and major economies across the globe are in recession. WTO Members have to break through the current negotiation deadlock and move on with further consultation, negotiation, and deliberation. In doing so, they should first ruminate on what went wrong in Cancún and contemplate how they can overcome those pitfalls to make meaningful progress. Without such a soul-searching diagnosis, no workable prescription can emerge. This paper seeks to make a contribution to this process of diagnosis and prescription.

The paper is premised on the concept of a 'trade constitution', which represents a 'very delicate mix of economic and governmental policies, political constraints, and above all an intricate set of constraints imposed by a variety of rules or legal norms in a particular institutional setting. ${ }^{1}$ No other concept can do a better job in capturing and explaining the recent phenomena that have occurred in Cancún. We have witnessed how domestic policies have influenced and constrained the operation of the WTO system. At the same time, however, the WTO norm must constrain those Member countries' policies in order to achieve the WTO's institutional goal or telos. In this context, 'trade constitution' is a useful conceptual tool for analyzing and evaluating current developments in the global trading system.

Part I sketches previous WTO Ministerial Conferences in an attempt to glimpse the roots of the problems that eventually caused the collapse of the Cancún Conference. Part II focuses on the main developments in Cancún and carries out a 'post-mortem', ${ }^{2}$ not in an attempt to place blame but to better understand what went wrong. Part III is devoted to prospects and suggestions. It observes that North-South tension is likely to continue for the

${ }^{1}$ John H. Jackson, The World Trading System: Law and Policy of International Economic Relations, 2nd edn (Cambridge, MA: MIT Press, 1997) 339; John H. Jackson, The World Trade Organization: Constitution and Furisprudence 101-04 (London: Royal Institution of International Affairs 1998); John H. Jackson, 'Reflections on International Economic Law', 17 U. Pa. J. Int'l Econ. L. (1996) 17, 2528; John H. Jackson, 'Perspectives on Regionalism in Trade Relations', 27 Law \& Pol'y Int'l Bus. (1996) 873. See also Antonio F. Perez, 'WTO and U.N. Law: Institutional Comity in National Security', 23 Yale J. Int'l L. (1998) 301, 316-24 (discussing Professor Jackson's constitutional premise of international trade law).

2 Cf. Sylvia Ostry, 'Making Sense of It All: A Post-Mortem on the Meaning of Seattle', in Roger B. Porter and Pierre Sauvé (eds), Seattle, the WTO, and the Future of the Multilateral Trading System (Harvard, CT: Center for Busines and Government, John F. Kennedy School of Government 2000) 81 . 
time being while rich countries, especially the US, will lean toward bilateralism and regionalism. Yet, it also suggests that with a combination of hard work by Member countries, political support from NGOs and businesses, and the Secretariat's constructive role, the Doha Round can and should be saved. The paper concludes that the global trading community is now embracing another 'constitutional moment', which parallels the creation of the GATT 1947 and the WTO.

\section{THE ROAD TO CANCÚN: PRE-CANCÚN MINISTERIAL CONFERENCES}

\section{A. Ambitious early years: Singapore (December 1996) and Geneva (May} 1998)

The WTO Charter, namely the Agreement Establishing the World Trade Organization, stipulates in Article IV:1 that 'There shall be a Ministerial Conference composed of representatives of all the Members, which shall meet at least once every two years'. ${ }^{3}$ Under this mandate, the first Ministerial Meeting was held in Singapore from 9 to 13 December 1996 to evaluate the implementation of Members' commitments under the WTO rules and to review the ongoing negotiations. ${ }^{4}$

Numerous issues, ranging from labor standards to the challenges of leastdeveloped countries (LDCs), were submitted and discussed, reflecting the fact that this was the very first WTO Ministerial Meeting since the historic launch of the WTO system. Although debates and discussions regarding most issues were compiled into rather fluid language in the final Ministerial Declaration, certain Members, including both developed and developing countries, successfully concluded a significant pact among themselves concerning freer trade in 'information technology products'. The 'Ministerial Declaration on Trade in Information Technology Products' requires each participating Member to 'bind and eliminate' tariffs and other charges with respect to a comprehensive range of information technology products, such as computers and their various parts and components. ${ }^{5}$

Despite this propitious achievement, there were also omens of the future fiasco in Cancún. A rift between developed and developing countries became apparent, centering on traditional North-South issues such as core labor standards, investment, and competition. As for core labor standards, developing countries succeeded in de-linking this issue from trade by

${ }^{3}$ Marrakesh Agreement Establishing the World Trade Organization, 15 April 1994, Final Act Embodying the Results of the Uruguay Round of Multilateral Trade Negotiations, art. IV, para 1 [hereinafter WTO Agreement], Legal Instruments - Results of the Uruguay Round [hereinafter Results of the Uruguay Round], 6, 6-18; 33 I.L.M. (1994) 1140, 1144-1153.

4 WTO, The Singapore Ministerial Declaration, adopted on 13 December 1996, WT/MIN(96)/DEC, http://www.wto.org/english/thewto_e/minist_e/min96_e/wtodec_e.htm [hereinafter the Singapore Ministerial Declaration].

${ }^{5}$ WTO, Ministerial Declaration on Trade in Information Technology Products, Singapore, 13 December 1996, WT/MIN(96)/16, http://www.wto.org/english/tratop_e/inftec_e/itadec_e.htm. 
stipulating that the International Labor Organization (ILO) is the competent body to handle this issue and that the use of labor standards for protectionist purposes should be rejected. ${ }^{6}$ In contrast, developed countries managed to push onto the WTO agenda hitherto controversial issues, such as investment and competition, which were later dubbed the 'Singapore issues'. ${ }^{7}$ Members agreed to establish 'working groups' to examine and study the relationship between trade and these issues. ${ }^{8}$

The Singapore Ministerial Declaration explicitly addressed potential problems that eventually contributed to the fall of the Cancún Conference several years later. It highlighted development concerns of the $\mathrm{LDCs}^{9}$ and warned against their 'marginalization' from the global trading system. ${ }^{10}$ It also urged 'full and faithful' implementation of the Agreement on Textiles and Clothing (ATC), particularly in a way that would help the world's poorest countries, including 'cotton-exporting' Members. ${ }^{11}$ Yet, rich countries have since failed to respond to this appeal from the LDCs, who submitted another desperate appeal in the form of the 'Cotton Initiative' in Cancún.

The second WTO Ministerial Conference was held in Geneva in May 1998 when East Asian countries still suffered from the dire aftermath of the financial crisis. This Ministerial Conference was supposedly more ceremonial than negotiational as 1998 was the 50th anniversary of the creation of the modern global trading system embodied by the GATT. However, two developments at this Conference merit attention. First, Ministers declared that protection is not the right approach to tackling the financial crisis. ${ }^{12}$ Second, Ministers adopted the 'Declaration on Global Electronic Commerce' in which they established a 'comprehensive work program' to examine all trade-related aspects of electronic commerce and pledged their continuous practice of exempting tariffs on electronic transmissions. ${ }^{13}$

\section{B. The Seattle debacle (December 1999)}

Despite seemingly propitious initiatives in the early years, developing countries became increasingly disappointed at the lack of developed

\footnotetext{
${ }^{6}$ This point was later reaffirmed in the Doha Ministerial Declaration. WTO, The Doha Ministerial Conference, adopted on November 14, 2001, WT/MIN(01)/1, para 8, http://www.wto.org/english/ thewto_e/minist_e/min01_e/mindecl_e.htm [hereinafter the Doha Ministerial Declaration].

7 They connote four issues: trade facilitation, transparency in government procurement, investment, and competition. Singapore Ministerial Declaration, above n 4, paras 20-23.

8 Id.

9 Id, para 14.

${ }^{10} \mathrm{Id}$, para 5.

11 Id, para 15.

12 WTO, The Geneva Ministerial Declaration, adopted 20 May 1998, WT/MIN(98)/DEC/1, para 3, http://www.wto.org/english/thewto_e/minist_e/min98_e/mindec_e.htm.

13 WTO, Declaration on Global Economic Commerce, adopted on 20 May 1998, WT/MIN(98)/DEC/ 2, http://www.wto.org/english/thewto_e/minist_e/min98_e/ecom_e.htm.
} 
countries' faithful implementation of what they had promised in the Uruguay Round. Developed countries continued to maintain high trade barriers on imports of those primary, labor-intensive goods, such as agricultural products and textiles on which developing countries hold a comparative advantage. This 'development deficit' ${ }^{\prime 4}$ costs poor countries over $\$ 100$ billion a year, which is twice the total amount of foreign aid from North to South. ${ }^{15}$ Developing countries complained of the 'uneven distribution'16 of benefits among Members and criticized the failure to realize the WTO's foremost telos, namely 'sustainable development'. ${ }^{17}$

Developing countries' disappointment had already turned to frustration when the Seattle Ministerial Meeting opened. This frustration could not be redressed by developed countries due to their lack of political will or political capital and only deepened a pre-existing rift between North and South, which is said to be the main culprit for the collapse of the Seattle Conference. ${ }^{18}$

Admittedly, the Seattle debacle may also be ascribed to other logistical factors besides the North-South tension. First, the Conference itself was illprepared. Members had already spent a great deal of energy in debating who should succeed Renato Ruggiero as the next WTO Director-General and negotiation committees were set up only weeks before the Conference. ${ }^{19}$ Hence, there was no workable text for negotiation to start with. ${ }^{20}$ Second, in an astonishing political gesture, the then-US President Bill Clinton expressly

14 Celso L.N. Amorim, 'The WTO from the Perspective of a Developing Country', 24 Fordham Int'l L.J. (2000) 95, 96-99 (criticizing 'development deficit' in the WTO in the areas of agriculture and textiles).

15 Globalization, Growth, and Poverty: Building an Inclusive World Economy 9, 53, A World Bank Policy Research Report (Washington, DC: World Bank, 2002) [hereinafter Globalization, Growth, and Poverty].

16 Cf. WTO, WTO News: Speeches - DG Mike Moore (23 September 1999), Africa and the Multilateral Trading System: Challenges and Opportunities, http://www.wto.org/english/news_e/spmm_e/ spmm07_e.htm. ('There must be something in the pie for everyone. Not pie in the sky when we die, but pie on the table'.).

17 WTO Agreement, above n 3, preamble.

18 'The Seattle WTO ministerial meeting failed to launch a new round, not because of the protests in the streets, but because the major trading powers lacked the political will to accommodate the interests of developing countries. ... In order for developing countries to have confidence in a new round, rich countries must deliver on commitments made in the past, such as accelerating the agricultural trade negotiations and phasing out quotas on textiles and clothing'. Globalization, Growth, and Poverty, above n 15, at 60 (quoting the recent report of the UN High-Level Panel on Financing for Development). Cf. Diana Tussie and Miguel F. Lengyel, 'Developing Countries: Turning Participation into Influence', in Bernard Hoekman et al. (eds), Development, Trade, and the WTO: A Handbook (2002) 485, 490 (observing that 'after the significant concessions made in the Uruguay Round, developing countries felt entitled to be included in the green-room process').

19 Supachai Panitchpakdi, 'Keynote Address: The Evolving Multilateral Trading System in the New Millennium', 33 Geo. Wash. Int'l L. Rev. 419, 427-28.

${ }^{20}$ Id. 
sympathized with demonstrators in the streets and vowed that he would push for linking labor standards to trade via sanctions. ${ }^{21}$ This was a cold shower to most developing countries, causing their frustration to turn to anger. Perhaps President Clinton did not realize that this issue was a fait accompli in the Singapore Ministerial Conference. Some of the protesters with whom he sympathized were, themselves, a substantial source of disruption. At the Seattle Conference, some Non-Governmental Organizations (NGOs) took steps to torpedo the proceedings, creating a great deal of chaos. Sadly, in doing so they also blocked the legitimate voices of many peaceful NGOs. Interestingly, this milieu also gave rise to such odd anti-WTO alliances as the 'Turtle-Teamster Partnership'. ${ }^{22}$

Beyond these problems, the general administration of the conference was not very methodical. Sylvia Ostry recollects that many delegates shared the view that this was one of the most poorly run international meetings that they had attended. ${ }^{23}$ Worse, the conference chair, the then-United States Trade Representative (USTR) Charlene Barshefsky, assumed the head of the US delegation, which, to many ministers, called into question the fairness of the conference. $^{24}$

\section{A new hope in Doha (November 2001)}

The fourth WTO Ministerial Conference, held in Doha, Qatar, in 2001, was conducted under tense circumstances. The Seattle debacle still haunted the WTO. Furthermore, the conference was mustered only two months after the September 11 terrorist attacks. Ironically, this tough atmosphere pressured delegates from both developed and developing countries to strike a deal and herald a propitious signal to the global trading community, which desperately sought a breakthrough in the face of the global recession and post-traumatic symptoms of the September 11 attacks.

The Doha agenda centered on development issues, giving rise to terms such as 'Doha Development Agenda (DDA)' and 'Development Round'. Even before the Doha Conference, a wide international consensus was formed on the priority of development in any trade deals. The UN Secretary-General, the World Bank President, and the IMF Managing Director all voiced an urgent need to address global poverty and an essential role of trade for this

21 Ostry, above n 2, at 81.

22 Id, at 90. See also Robert Howse, 'Managing the Interface between International Trade Law and the Regulatory State: What Lessons Should (and Should Not) Be Drawn from the Jurisprudence of the United States Dormant Commerce Clause', in Thomas Cottier and Petros C. Mavroidis (eds), Regulatory Barriers and the Principle of Non-Discrimination in World Trade Law (Ann Arbor: University of Michigan Press, 2000) 147 (citing David Vogel's notion of 'Baptist-bootlegger alliances').

23 Ostry, above n 2, at 82-83.

24 Id, at 83. 
objective. $^{25}$ Reflecting such serious consideration in the international community, the Doha Ministerial Conference produced clear negotiation objectives, transitional deadlines and detailed 'work programs' on the DDA, even highlighting 'well targeted, substantially financed technical assistance and capacity-building programs'. ${ }^{26}$

In an ambitious move, the Doha Ministerial Declaration nailed down a final deadline of 1 January 2005, as the date for completing the Doha Round. Apart from the main Ministerial Declaration, the Doha Conference succeeded in issuing two important development-related legal documents: 'Declaration on the TRIPs Agreement and Public Health', ${ }^{27}$ which endorses Members to grant compulsory licenses in the face of public health crises, and 'Decision of 14 November 2001 on Implementation', which spells out implementation-related issues and concerns. ${ }^{28}$ At the same time, however, the Ministerial Declaration also left ground for future negotiation of the Singapore issues. ${ }^{29}$

\section{THE MAIN FIELD: CANCUN MINISTERIAL CONFERENCE (SEPTEMBER 2003)}

\section{A. Background}

In January 2002, Member countries assembled for the first meeting of the Trade Negotiations Committee (TNC) to begin working on the Doha Agenda. ${ }^{30}$ The TNC established seven negotiating bodies for agriculture, services, non-agricultural market access, rules, trade and environment, a multilateral register for geographical indicators for wines and spirits, and reform of the Dispute Settlement Understanding (DSU). ${ }^{31}$ Subsequently,

25 Development: Annan Calls for 'Development Round' of Trade Talks, UN Wire, 19 September 2000, http://www.unwire.org/UNWire/20000919/10846_story.asp. World Bank President James Wolfensohn also warned that 'global poverty and the resulting social unrest threatens to destabilize developed countries' and that 'it is in their interest to bring about poverty alleviation in the developing world because we are one world and, unless we get stability and growth in the developing world, we are not going to have a peaceful world'. IMF/World Bank: Wolfensohn Promotes Equitable Growth, UN Wire, 22 September 2000, http://www.unwire.org/UNWire/20000922/10924_story.asp. Cf. Frederick M. Abbott, 'The Enduring Enigma of TRIPS: A Challenge for the World Economic System', 1 JIEL (1998) 497 (arguing that developed countries' emphasis on the static protection of intellectual property rights is misplaced and that such emphasis on maintaining technological advantage is a 'beggar-thy-neighbour' approach incompatible with an integrating world economy).

26 The Doha Ministerial Declaration, above n 6, para 2. See also id, paras 38-41.

27 WTO, Declaration on the TRIPS Agreement and Public Health, adopted on 20 November 2001, WT/MIN(01)/2, http://www.wto.org/english/thewto_e/minist_e/min01_e/mindecl_trips_e.htm.

28 WTO, Decision of 14 December 2001, WT/MIN(01)/17, http://www.wto.org/english/thewto_e/ minist_e/min01_e/mindecl_implementation_e.htm.

29 The Doha Ministerial Declaration, above n 6, paras 20-27.

30 WTO, The Doha Developing Agenda: Doha Launches Negotiations, TNC Oversees Them, www.wto.org/ english/thewto_e/minist_e/min03_e/brief_e/brief02_e.htm.

31 Id. 
most negotiations were conducted in a 'special session' of each corresponding committee or council. ${ }^{32}$ This initial grandiose march for a new Round soon became a slow and tedious process. Although Members reached a certain consensus on the general framework of the Doha Round, they faced difficulties in implementing them, mainly because most agendas were politically sensitive, requiring a good deal of concession and contribution, in particular from the developed countries. The devil was in the details.

Although the Doha Declaration is full of verbal commitments and plans for capacity building, it is silent about how to fund the ambitious technical assistance programs. Furthermore, its legal nature as a 'work program' is vague. One might reasonably speculate that this document would not be enforceable through the WTO dispute settlement mechanism since the DSU applies only to 'covered agreements'. ${ }^{33}$ Therefore, the success of all capacity building, which is critical to developing countries to integrate their fragile economies into the global trade stream, is at the mercy of a handful of wealthy Member countries, which have not been generous in this regard in the past.

More recently, while disappointing trade figures urge progress in trade negotiations, ${ }^{34}$ a new US farm bill introducing $\$ 180$ billion in subsidies over the next decade and the EU's failure to reform its Common Agricultural Policy (CAP) have made a 'mockery of the idea that the Doha round was to be a development round'. ${ }^{35}$ Many world leaders, including the heads of international organizations such as the IMF, World Bank, and the OECD, once again urged developed countries to eliminate their protection against developing countries' market access in agriculture and textiles. ${ }^{36}$ The Cancún Ministerial Conference was held against this rather depressing background. The only good news came just before the opening of the conference. Developed countries, in particular the US, agreed on certain legal changes that enabled certain developing countries, which cannot manufacture essential medicines themselves, to import cheaper generics produced under compulsory licensing in other countries. ${ }^{37}$ Ironically, this concession from rich countries cost them their political capital, which militated against a possible compromise in Cancún.

32 Id.

33 Understanding on Rules and Procedures Governing the Settlement of Disputes, Annex 2 of the WTO Agreement, above n 3, art. 1, para 1.

34 TRADE: WTO Says Slowdown Underscores Need for Progress on Doha, UN Wire, 11 October 2002, http://www.unwire.org/UNWire/20021011/29596_story.asp.

35 'World Trade: Coming Unstuck', The Economist (2 November 2002), at 14; 'The Zoellick Plan: Trading Insults', The Economist (30 November 2002), at 67.

36 See e.g., Declaration by the Heads of the IMF, OECD and World Bank, http://www.oecd.org/ document/9/0,2340,en_2649_201185_11813577_1_1_1_1,00.html.

37 WTO TRIPs Council, Decision of 30 August 2003: Implementation of paragraph 6 of the Doha Declaration on the TRIPS Agreement and public health, WT/L/540, http://www.wto.org/english/ tratop_e/trips_e/implem_para6_e.htm. 


\section{B. The negotiation: main developments}

\section{Modus operandi: five subjects and five facilitators}

The conference chair, Mexican Foreign Minister Luis Ernesto Derbez, invited five ministers to act as 'facilitators'. Their role was similar to 'friends of the chair' at the Doha Ministerial Meeting, ${ }^{38}$ where they functioned as de facto 'deputies' to the chair who moderated and coordinated actual negotiations among individual groups and delegations. Based on reports by facilitators, the chair launched informal meetings with heads of delegations. ${ }^{39}$

These five facilitators corresponded with five negotiation agendas: 'agriculture' (George Yeo Yong-Bon, Singapore's Trade and Industry Minister); 'non-agricultural market access' (NAMA) (Henry Tang Yingyen, Hong Kong China's Financial Secretary); 'development' (Mukhisa Kituyi, Kenya's Trade and Industry Minister); 'Singapore issues' (Pierre Pettigrew, Canada's International Trade Minister); and 'other issues' (Clement Rohee, Guyana's Foreign Trade and International Cooperation Minister). ${ }^{40}$

\section{Agriculture: the real hardcore}

Agriculture, in particular the issue of farm subsidies, was a defining agenda of the Cancún Conference. All eyes were fixed upon these negotiations. Although the Doha Declaration committed Member countries, in particular developed countries, to phasing out 'all forms of export subsidies' and substantially reducing 'trade-distorting domestic support', ${ }^{41}$ actual negotiations since that time have done little more than reveal a diametrical difference in positions between North and South. Member countries failed to agree even on 'modalities' of the negotiations, a task that was to be completed by the deadline of 31 March $2003 .^{42}$

As the Cancún Conference drew on, the US and the EU took initiative and issued a joint position on the agriculture negotiations. Although this joint position, announced on 13 August 2003, ${ }^{43}$ did break the inertia of the long hibernating agricultural negotiations, it was weak and watered down relative to previous proposals discussed in Geneva. ${ }^{44}$

38 WTO, Summary of 10 September, 2003, Day 1: Conference kicks off with 'facilitators' named and cotton debated, http://www.wto.org/english/thewto_e/minist_e/min03_e/min03_10sept_e.htm [hereinafter WTO, Day 1].

39 Id.

40 Id.

41 The Doha Ministerial Declaration, above n 6, para 13.

42 Id, para 14.

43 United States Department of Agriculture (USDA), Statement, Regarding the US-EU Framework for WTO Agricultural Negotiations, 13 August 2003, www.usda.gov/news/releases/2003/08/ 0287.htm.

44 Bridges Daily Update on the Fifth WTO Ministerial Conference, Issue 1, Cancun Ministerial: Setting the Stage, 10 September 2003, http://www.ictsd.org/ministerial/cancun/wto_daily/ben030910.htm [hereinafter Bridges, Issue 1]. 
First of all, no detailed 'timeframes or figures to cut' existed. ${ }^{45}$ In substance, the EU and the US limited the elimination of export subsidies (amber box) ${ }^{46}$ to 'products of particular interest to developing countries' ${ }^{47}$ In the reduction of other forms of trade-distorting domestic support (blue box), they created a new category of 'less trade-distorting domestic support' which would have no production limit and could possibly open the door to legalizing the 2002 US Farm Bill. ${ }^{48}$ In terms of trade-neutral domestic support (green box), they surprisingly failed to deliver any provisions. ${ }^{49}$ This joint paper was severely criticized by developing countries led by Brazil, India, and China, who also presented their own proposal. ${ }^{50}$

Originally, the US-EU joint paper did provide a base text for the agriculture negotiations. ${ }^{51}$ However, the initial dissenters, Brazil, India, and China, eventually succeeded in persuading other developing countries to form a coalition dubbed ' $\mathrm{G}-21$ ', despite the fact that some members of the G-21 faced pressure from the US and the EU not to join. ${ }^{52}$ Their proposal called for the elimination of export subsidies on all products. Ultimately, the initial joint US-EU text was withdrawn by Conference Chair Derbez. ${ }^{53}$

Notably, the US-EU coalition in agriculture seemed to be a bit awkward considering their traditionally contrasting positions on this subject. The US, having a strong export interest in agriculture, took an offensive position in the agricultural negotiation. Its technology-driven, extensive farming industry exports a quarter of its total production, which amounted to $\$ 57$ billion during the 2002 fiscal year. ${ }^{54}$ Highlighting an overriding objective in its agricultural trade talks to 'gain greater market access', USDA Secretary Ann

45 Id.

46 Regarding three different modalities of agricultural subsidies (amber, blue, and green box), see generally WTO, Agricultural Negotiations, Background Fact Sheet, Domestic Support in Agriculture: The Boxes, http://www.wto.org/english/tratop_e/agric_e/agboxes_e.htm.

47 'Agriculture: Real Negotiations Start as EC, US Table Joint Modalities Text', Bridges Weekly Trade News Digest, Vol. 7, No. 28, 21 August 2003, http://www.ictsd.org/weekly/03-08-21/index.htm.

48 Id.

49 Id.

50 Developing Countries Present Farm-Trade Plan to WTO, UN Wire, 21 August 2003, http:// www.unwire.org/UNWire/20030821/449_7715.asp.

51 Bridges, Issue 1, above n 38.

52 Rolf Kuntz, G-21 consegul nivelar campo para ojogo agrícola, 11 September 2003, www.estado.estadao.com.br; Protests Dies at WTO Talks; Draft Agriculture Plan Withdrawn, UN Wire, 11 September 2003, http://www.unwire.org/UNWire/20030911/449_8349.asp [hereinafter UN Wire, 11 September]; Bridges Daily Update on the Fifth WTO Ministerial Conference, Issue 2, 'Cotton - "The TRIPs and Health" of Cancun?', 11 September 2003, http://www.ictsd.org/ministerial/cancun/wto_daily/ ben030911.htm [hereinafter Bridges, Issue 2].

53 UN Wire, 11 September above n 52.

54 United States Department of Agriculture, News Release (No. 0230.01), Historic Opportunity for U.S. Farmers as New Agenda for Trade Negotiations Are Launched in Qatar, 14 November 2001, www.usda.gov/news/releases/2001/11/0230.htm. 
Veneman stated that 'Expanding global markets for our farmers is vital to the long-term prosperity of our highly productive agriculture and food sector'. ${ }^{55}$ Therefore, the US could maintain a relatively flexible position, willing to cut farm subsidies if such a reduction corresponded to an increase in market access to US trading partners, including the EU. ${ }^{56}$

In contrast, the EU's position, though still suffering an internal cacophony, ${ }^{57}$ was much more defensive as a result of its controversial Common Agricultural Policy (CAP). While the EU joined the US in demanding increased market access to developing countries, it insisted more strongly on the expansion of geographical indications and direct payment for high environmental protection to make up the loss of its export market. ${ }^{58}$ One might reasonably suspect that the EU's insistence on the expansion of geographical indications in areas other than wine and spirits, for instance certain ham and cheese, was intended to collect bargaining chips for future agriculture negotiations, considering that very few Member countries are enthusiastic about this issue. In fact, Canada's Trade Minister Pierre Pettigrew warned against this proposal, describing it as 'open[ing] a Pandora's box that will take decades to close'. ${ }^{59}$

There are two possible explanations for this implausible coalition between the US and the EU. First, President Bush's bold Farm Bill issued in 2002, which would provide farm subsidies amounting to $\$ 180$ billion over the next decade, forced the US to jump on the EU's protectionist bandwagon. Second, the two economic superpowers may have been attempting to pre-empt the negotiations by submitting a joint text that would have formed the basis of the subsequent negotiations in Cancún. Of course, this attempt proved to be futile in the face of the developing countries' coalition, i.e., the G-21.

Unfortunately, days of intense negotiations only reaffirmed diverging stances among Member countries on the issue of agriculture. While the EU objected to the capping of trade-distorting domestic support (blue box) and agreed to eliminate export subsidies (amber box) only on a selective basis, the G-21 argued that such a proposal was deficient and unacceptable. ${ }^{60}$ Perhaps only a few days of negotiations in Cancún were simply not enough to resolve such a difficult issue, particularly with a subject so closely linked to the 'Singapore issues'.

55 Id.

56 Bridges, Issue 2, above n 52.

57 Bridges, Issue 1, above n 44.

58 Bridges, Issue 2, above n 52.

59 Id.

${ }^{60}$ Bridges Daily Update on the Fifth WTO Ministerial Conference, Issue 5, 'At the Eleventh Hour, Divergence All Over Again', 14 September 2003, http://www.ictsd.org/ministerial/cancun/wto_daily/ ben030914.htm [hereinafter Bridges, Issue 5]. 


\section{The cotton proposal}

Four cotton-producing countries (Benin, Burkina Faso, Chad, and Mali) located in West and Central Africa submitted a desperate proposal, which was rather a plea, demanding that rich countries eliminate their subsidies to cotton farmers and that due compensation be paid to these four countries for economic damages resulting from these subsidies. ${ }^{61}$ This proposal was in fact aimed at the world's largest cotton subsidizer, the US. Markedly, the proposal demonstrated a textbook example of the pernicious effects of a subsidy. These countries retain a comparative advantage on cotton production thanks to their cheap labor and natural endowments. They are also highly dependent on the export of cotton, which amounts to 80 percent of their export earnings. ${ }^{62}$ However, they still cannot compete in the market with heavily subsidized and thus artificially low-priced cotton from rich countries. Their proposal was so appealing that WTO Director-General Supachai invited himself to chair the negotiation of the proposal. He pointed out that these countries were not asking for any special favors, but merely for all nations to play by the rules. ${ }^{63}$

Despite broad support of the proposal from both developed and developing countries, the US issued a de facto rejection of the proposal as it argued that subsidies are not the sole culprit for market distortions. The US listed other factors, such as 'good harvests', as contributory to falling cotton prices. ${ }^{64}$ It also suggested that these countries should 'diversify' their production away from cotton to textiles so that they are subject to preferential market access to the US under its 'African Growth and Opportunity Act'. ${ }^{65}$ The four African countries that submitted the proposal, and their supporters, were deeply frustrated by the US refusal to eliminate subsidies, even to the world's poorest countries. ${ }^{66}$ One African cotton producer reportedly said,

'We are used to hardship, disease and famine. Now the WTO is against us as well. I think that this will stay in history ... ${ }^{, 67}$

\section{Singapore issues: the conference-buster}

Singapore issues, in particular investment and competition, were mirror images of agriculture in Cancún. As in agriculture, North and South were split diametrically over these matters. While developed countries generally advocated that the WTO should reflect the realities of the ever-growing

${ }^{61}$ Bridges Daily Update on the Fifth WTO Ministerial Conference, Issue 3, 'Will Chair's AG Text Warm Up Frozen Talks?', 12 September 2003, http://www.ictsd.org/ministerial/cancun/wto_daily/ ben030912.htm [hereinafter Bridges, Issue 3].

62 Bridges, Issue 2, above n 52.

63 WTO, Day 1, above n 38.

${ }^{64}$ Id.

65 Bridges, Issue 2, above n 52.

${ }^{66}$ Bridges, Issue 5, above n 60.

${ }^{67} \mathrm{Id}$. 
relevance of these issues to trade, developing countries generally feared that this linkage might undermine their comparative advantage or function as disguised discrimination, i.e., create new trade barriers against developing countries' exports in the name of investment and competition. This tension, hearkening back to the Singapore Ministerial Conference, was left unresolved in the Doha Ministerial Conference, which only rendered vague suggestions regarding future negotiations on these issues. That is, while negotiations would take place in Cancún, ${ }^{68}$ their 'modalities' would be decided by an 'explicit consensus' of Member countries. ${ }^{69}$

Not surprisingly, the tension continued in Cancún. Many developed countries, including the EU as a main proponent, characterized the Singapore issues as being just as 'integral' to the Doha Round as agriculture, and that negotiations on these issues should be launched immediately considering the demands for enhanced rules by international business. ${ }^{70}$ In contrast, many developing countries, including China, India, Malaysia, and Nigeria, argued that these issues should be sent back to Geneva for further study and clarification in the absence of 'explicit consensus' among Member countries and that they should be de-coupled from other issues on the table. ${ }^{71}$ As a third approach, some developing countries suggested that each Singapore issue should be considered 'on its own merits' and supported negotiations on less controversial issues, i.e., trade facilitation and transparency in government procurement. ${ }^{72}$

Nonetheless, Pierre Pettigrew, the facilitator for negotiations of Singapore issues, noted that he encountered plausible suggestions for compromise, such as breaking the whole into four individual issues and negotiating each at a different pace, explicitly exempting some issues from the WTO dispute settlement procedure, and creating plurilateral agreements on an issue-byissue basis. ${ }^{73}$

\section{Closing moments}

By the eve of the last day of the conference, Members had still not narrowed their differences, especially in the areas of farm subsidies and the Singapore issues. After discovering that 'speech after speech' in a meeting with the heads of the delegations had been devoted to the Singapore issues, Conference Chair Derbez decided to focus on these issues during the last set of

\footnotetext{
68 The Doha Ministerial Declaration, above n 6, paras 20, 23.

${ }^{69}$ Id.

70 WTO, Summary of 11 September, 2003, Day 2, Cambodia and Nepal membership sealed as ministers start negotiations, http://www.wto.org/english/thewto_e/minist_e/min03_e/min03_11sept_e.htm [hereafter WTO, Day 2]; Bridges, Issue 1, above n 44; Bridges, Issue 3, above n 61.

71 WTO, Day 2, above n 70; Bridges, Issue 1, above n 44; Bridges, Issue 3, above n 61.

72 WTO, Day 2, above n 70.

${ }^{73}$ Bridges, Issue 3, above n 61.
} 
consultations, which were conducted until early Sunday afternoon. ${ }^{74}$ Many observers, however, wondered why Derbez prioritized the Singapore issues over agriculture when many Member countries, both developed and developing, had insisted that progress in the Singapore issues should be linked to developments in agriculture negotiation. ${ }^{75}$

After intense last-ditch consultations with a larger group of countries, Derbez suspended the consultations for a one-hour recess to allow these countries to speak with their regional or other groupings. ${ }^{76} \mathrm{Up}$ to this very moment, there was still a ray of hope. During these consultations, signs of flexibility began to show. For instance, the EU was reportedly prepared to drop controversial investment and competition issues out of the Doha Agenda. ${ }^{77}$

Yet, when Member countries returned after the recess to the green room, the concessive atmosphere suddenly evaporated, and positions stiffened once more. ${ }^{78}$ Botswana declared on behalf of the African Union that they would not accept any deal that included any of the Singapore issues. ${ }^{79}$ In stark contrast, Japan and Korea insisted that all four Singapore issues should be included in any kind of deal. ${ }^{80}$ Facing a stalemate, Derbez, in yet another unexpected move, closed the entire Conference by concluding that he did not see any possibility of deal-making within the time remaining. ${ }^{81}$ Once again, many observers were puzzled by Derbez's decision. China and the EU actually attempted to stop this decision by arguing that there might still be a chance to save the conference. ${ }^{82}$ Patricia Hewitt, the United Kingdom Secretary of State for Trade and Industry, later criticized the decision as 'premature'.

Shortly after his decision to close the conference, Derbez proposed a onepage, six-paragraph Ministerial Statement, which was adopted in the closing session at around $6 \mathrm{pm}$ on Sunday. ${ }^{83}$ This statement essentially sent the negotiations back to Geneva where a General Council meeting would meet no

${ }^{74}$ WTO, Summary of 14 September, 2003, Day 5, Conference ends without consensus, http:// www.wto.org/english/thewto_e/minist_e/min03_e/min03_14sept_e.htm [hereinafter WTO Day 5]; Bridges Daily Update on the Fifth WTO Ministerial Conference, Issue 6, 'Cancun Collapse: Where There is No Will There is No Way', 15 September 2003, http://www.ictsd.org/ministerial/cancun/ wto_daily/ben030915.htm [hereinafter Bridges, Issue 6].

75 Bridges, Issue 6, above n 74.

76 WTO Day 5, above n 74; Bridges, Issue 6, above n 74 .

77 Bridges, Issue 6, above n 74.

78 WTO Day 5, above n 74; Bridges, Issue 6, above n 74 .

79 Bridges, Issue 6, above n 74 .

${ }^{80}$ Id.

81 WTO Day 5, above n 74; Bridges, Issue 6, above n 74 .

82 Bridges, Issue 6, above n 74.

${ }^{83}$ WTO Day 5, above n 74; Bridges, Issue 6, above n 74 . 
later than 15 December $2003 .^{84}$ The only silver lining was the acceptance of Cambodia and Nepal as new Members. ${ }^{85}$ The Fifth Ministerial Conference in Cancún officially failed, making it the second major setback, along with the Seattle debacle, since the encouraging launch of the WTO.

\section{Coda}

The demise of the Cancún Conference was soon followed by an inundation of announcements and press releases by different governments and institutions. Markedly, a North-South line was also salient in this blame game: Developed and developing countries pointed their fingers at each other. The US mostly found fault with developing countries' intransigent stance and lack of their own concessions, particularly in the area of market opening in the agricultural sector. The USTR Robert Zoellick impliedly stated that the 'rhetoric' of 'won't do' employed by developing countries led to the impasse. ${ }^{86}$ US Senator Chuck Grassley, Chairman of the Finance Committee, released a similar announcement that 'some participants seemed to be more satisfied with hollow rhetoric than real negotiation' ${ }^{87}$ The EU was more low-key. Instead of criticizing developing countries, the EU Trade Commissioner, Pascal Lamy, ascribed the collapse to the 'medieval' decision-making process in the WTO. ${ }^{88}$

On the contrary, developing countries - as well as most NGOs - criticized rich countries' lack of willingness to open their markets to poor countries. African countries expressed their disappointment concerning a lack of consideration from developed countries on agriculture and other development issues. ${ }^{89}$ The G-21 refuted the notion that their inflexibility sunk the conference but expressed their collective satisfaction with the unity that they showed in the conference. ${ }^{90}$ NGOs voiced in unison their strong criticism against the inertia by rich countries, in particular the US and the EU, in their stances on agriculture and other development-related issues. Greenpeace

84 Ministerial Statement, Ministerial Conference, The Fifth Session, adopted on 14 September 2003, WT/MIN(03)/20, http://www.wto.org/english/thewto_e/minist_e/min03_e/min03_20_e.doc [hereinafter The Cancún Statement].

85 Id.

${ }^{86}$ USTR, Press Release, 'Statement of U.S. Trade Representative Robert B. Zoellick', 14 September 2003.

87 The Office of the US Senator Chuck Grassley, Memorandum: Collapse of Trade Negotiations in Cancún, 14 September 2003 [hereinafter Grassley Memorandum].

88 Bridges, Issue 6, above n 74 .

89 Id.

90 Id. One anonymous commentator on an earlier version of this article observed that: 'G-21 served a useful purpose at Cancún because it avoided the acceptance of a bad deal in agriculture. It is too early in the negotiations for the developing world to accept the US-EC proposal, which is very limited'. 
declared 'USA and EU sink the WTO Round in Cancún'. ${ }^{91}$ Oxfam also observed that the US and the EU 'wrecked' WTO trade talks. ${ }^{92}$ Likewise, the Public Citizen noted that the conference collapsed when the US and the EU 'stubbornly rejected the demands of the majority of the organization's signatory nations to make the global trade rules more fair'. ${ }^{93}$

In hindsight, one might bring to mind a host of factors that are cumulatively accountable for the fall of the Cancún Ministerial Conference. ${ }^{94}$ First, a general lack of preparation: Since the Doha Conference, Member countries had been unable to narrow down the gap in their diverging, often in a diametrical fashion, stances in the core Doha agenda items, such as farm subsidies and the Singapore issues. In fact, Member countries should have come to Cancún with a solid negotiational text containing a reasonable amount of brackets to complete the Doha Round as scheduled by the end of $2004 .{ }^{95}$ Yet, Member countries convened without a realistic text that could have established a deal during the five-day period of negotiations.

In fact, the first factor is associated with the second one: The core Doha agenda items, including agricultural issues and the Singapore issues, were all politically sensitive. To politicians of developed countries, the elimination of long-standing farm subsidies might mean the overnight loss of the local farmer support, which could cost them their next elections. To governments of developing countries, accepting the Singapore issues might mean placing a Trojan horse in their own backyard. Developing countries fear that developed countries legitimize the latter's new trade barriers in the name of investment and competition, eventually restricting the import of agricultural products and textiles from the former, thereby blocking the realization of the former's comparative advantage.

Thirdly, developed countries, in particular the US, may have felt deprived of sufficient political capital to enable them to accept demands from developing countries after they had already made the important concession of allowing certain developing countries to import generic medicine. ${ }^{96}$ Indeed, US Senator Grassley highlighted this very fact in Cancún and criticized the lack of reciprocal flexibility from developing countries. ${ }^{97}$

91 Greenpeace, News Release, 'USA and EU Sink the WTO Round and We Call on Governments to Create a New Trade System', 14 Sepember 2003.

92 Oxfam, Press Release, 'Rich Countries Wreck WTO Trade Talks', 14 September 2003.

93 Public Citizen, Statement of Lori Wallach, Director of Public Citizen's Global Trade Watch, 14 September 2003.

94 See notably Gary Clyde Hufbauer, 'The WTO: Are Past Glories a Prologue to Future Failures?', Eldon D. Foote Lecture 2003, University of Alberta, 30 October 2003 [hereinafter Hufbauer, Foote Lecture].

95 See Guy de Jonquires and Frances Williams, 'WTO Ministers Racing to Make Up Lost Time', Financial Times (8 September 2003), www.ft.com.

96 See above text accompanying $\mathrm{n} 37$.

97 Grassley Memorandum, above n 87. 
Last but not least, the 'China factor' enabled the creation of the G-21. Even before China entered into the WTO, Brazil and India, as 'super' developing countries, often acted as the voice for other developing countries. But with China in their ranks, the size and impact of this coalition became unprecedented. Although political balance sheets of individual participants of the G-21 were not necessarily homogenous, its symbolic unity that was developed and maintained in Cancún was powerful enough to defy developed countries' pressure.

\section{Quo Vadis WTO?: POST-CANCÚN PROSPECTS}

\section{A. North versus South: revisited}

The North-South tension witnessed in Cancún is not new, as demonstrated by the Seattle debacle. Yet, in Cancún it was revealed in a more dramatic fashion for reasons mainly attributable to the South. First, major developing countries, including India, Brazil, and China, succeeded in orchestrating their efforts into a common stance against developed countries on major negotiation topics such as agriculture even before the Cancún Conference began. When the US and the EU announced their joint position on farm subsidies in August 2003, these developing countries immediately denounced the position and issued their own version of the negotiation text. ${ }^{98}$ In addition, as mentioned above, the 'China factor' certainly invigorated this movement. According to one commentator, the G-21 countries 'have at least shamed the rich world into silence'. ${ }^{99}$

Another significant development in Cancún in relation to North versus South was a rally of most NGOs behind developing countries. As seen in numerous announcements released in reaction to the fall of the Cancún Conference, most high-profile NGOs, such as Greenpeace, Oxfam, and Public Citizen, explicitly backed the developing countries' stand and heavily criticized developed countries, in particular the US and the EU, for a lack of consideration for their poorer trading partners. ${ }^{100}$ This NGO patronage for developing countries and the LDCs may invite two interesting consequences.

First, as NGOs become more attached to developing countries and their agendas, developing countries may retain more leverage against developed countries in future negotiations. On the other hand, considering that developing countries account for three-fourths of the whole WTO membership, these NGOs' backing of developing countries tends to engage the NGOs more deeply in WTO business. These engagement dynamics are likely to lay a

\footnotetext{
98 Developing Countries Present Farm-Trade Plan, UN Wire, 21 August 2003, http://www.unwire.org/ UNWire/20030821/449_7715.asp.

99 Jonathan Eyal, 'G21 - A Flimsy Alliance Doomed to Fail', The Straits Times (27 September 2003).

100 See above text accompanying nn 91-93.
} 
fertile ground for better understanding and communication between NGOs and the WTO, although such understanding and communication does not necessarily mean that they will endorse the legitimacy of the WTO in general.

Second, NGOs have their own domestic constituencies, as evidenced in the performance of Ralph Nader and his Green Party in the 2000 US presidential election. This means that their continuous campaigning in the domestic arena for developing countries' interest, such as the elimination of farm subsidies, may have some influence in reshaping local politics and, subsequently, trade policies. The current 'left-leaning' political climate in Europe also tends to support this observation. ${ }^{101}$ In sum, NGOs that espouse and represent developing countries may neutralize local protectionism to a certain extent.

In prospect, it is likely that the North-South tension will continue for the time being as long as the Doha Development Agenda is left unresolved. However, one should not accept a fanciful notion that developing countries will always voice a unified position. The well-orchestrated stance of the G-21 in Cancún was in fact pre-deliberated and mainly for the sake of the Cancún Conference. ${ }^{102}$ One could not confidently predict that their stance will remain as solid in the future as it was in Cancún. Interests of G-21 members are not homogenous. For instance, while India still wants to protect domestic agricultural industries, Brazil, a member of the Cairns Group consisting of agricultural product exporters, wants to further liberalize trade in this area. ${ }^{103}$ Moreover, we witnessed other groups of developing countries, such as the G33, which advocated the inclusion of strategic products and a special safeguard mechanism in the agriculture negotiation; the coalition of the African Union, the African, Caribbean, and Pacific countries, and the LDCs (AU/ACP/LDCs) which collectively want the preservation of current preferential treatment in addition to G-33 demands. ${ }^{104}$ Obviously, future dynamics among these groups will play a decisive role in the upcoming negotiation. ${ }^{105}$

At the same time, the inevitable North-South tension should not serve to endorse the maintenance of trade barriers by developing countries themselves. As Jagdish Bhagwati trenchantly observes, many developing countries are still imposing high tariffs and other protectionist measures against both

101 See Tobias Buck, 'Cancun Summit: Lamy Returns Home to Face Anger and Disappointment', Financial Times (16 September 2003), www.ft.com.

102 See Guy de Jonquières and Frances Williams, 'Third World Alliance Hits at Trade Rules', Financial Times (10 September 2003), www.ft.com.

103 Eyal, above n 99.

104 Bridges Daily Update on the Fifth WTO Ministerial Conference, Issue 4, New Ministerial Text to Be Issued Today, 13 September 2003, http:/www.ictsd.org/ministerial/cancun/wto_daily/ ben030913.htm [hereinafter Bridges, Issue 4].

$105 \mathrm{Id}$ 
developed and developing countries. ${ }^{106}$ In particular, protectionism among developing countries not only is pernicious to their economic welfare but also tends to provide developed countries with a subterfuge for maintaining their own protection against developing countries.

\section{B. Bilateralism, regionalism, and unilateralism}

As multilateralism loses steam with the setback in Cancún, alternative avenues of trade negotiations, such as bilateral and regional trade agreements, seem to be spotlighted. The prospect of these types of agreements appears even more likely considering an ongoing series of bilateral trade agreements that the US has recently completed or worked on with many trading partners. The US has already sealed a bilateral free trade agreement (FTA) deal with Jordan (24 October 2000), Singapore (6 May 2003), Chile (6 June 2003), and Australia (8 February 2004), and is negotiating similar deals with Morocco, Central American countries, and the Southern African Customs Union (SACU) members. ${ }^{107}$ The US is also pushing forward the ambitious Free Trade Agreement of the Americas (FTAA). ${ }^{108}$ As US Senator Grassley announced, the US has a lot of 'options' including bilateral and plurilateral fronts in trade negotiations. ${ }^{109}$

Not surprisingly, this non-multilateral approach tends to better serve the interest of most US politicians and high-ranking civil servants. Considering their short life-cycle defined by elections, this approach may be more efficient than a multilateral one in 'making their mark in the shortest possible time', thus aiding their chances of re-election. ${ }^{110}$ Moreover, this approach tends to put a hegemon like the US in a position to wring a better deal from its weaker counterparts in the FTAs. ${ }^{111}$ At the same time, in smaller deals on FTAs, it is much easier to accommodate protectionist demands from local industries than in multilateral deals. ${ }^{112}$ Yet, it would be dispiriting to witness such an

106 Jagdish Bhagwati, Wanted: Fubilee 2010 (Dismantling Protection), 26 June 2002, http://www.oecdobserver.org/news/fullstory.php/aid/713/Wanted:_Jubilee_2010.html [hereinafter Bhagwati, Fubilee 2010].

107 USTR, USTR Resources, Free Trade Agreement Negotiations, www.ustr.gov/new/fta

108 USTR, World Regions, Western Hemisphere: Free Trade Area of the Americas (FTAA), www.ustr.gov/regions/whemisphere/ftaa.shtml

109 Grassley Statement, above n 87.

110 Raymond Vernon et al., Iron Triangles and Revolving Doors: Cases in US Foreign Economic Policymaking (New York: Praeger, 1991) 15.

111 See Jagdish Bhagwati, A Stream of Windows: Unsettling Reflections on Trade, Immigration and Democracy (Cambridge, MA: MIT Press, 1998) 309 (attacking the US 'FTA-cum-301 selfish hegemon strategy' as totally unfair).

112 See Edward Alden, 'Cancun Summit: Protectionist Pressure Building Up', Financial Times (16 September 2003), www.ft.com [hereinafter 'Protectionist Pressure Building Up']. 
important and powerful country as the US abandoning the multilateral forum that it invested so much in to create. ${ }^{113}$

Although some American scholars view that the move to bilateralism and regionalism will eventually benefit multilateralism, ${ }^{114}$ one cannot deny that FTAs are inherently preferential and discriminatory vis-à-vis non-members, which renders this alternative problematic. Admittedly, regionalism may contribute to multilateralism under certain circumstances through a 'laboratory effect'. ${ }^{115}$ After experiencing trial and error as well as learningby-doing in the regional level, countries may feel confident in ratcheting these regional initiatives up to the multilateral forum. ${ }^{116}$ However, the Guild nature of FTAs tends to materialize mercantilist outcomes among their members at the expense of non-members. ${ }^{117}$

For example, FTAs' complicated rules of origin, which are often compared to a 'spaghetti bowl', ${ }^{118}$ create an obstacle for non-members seeking to get an access to FTA members' markets, thereby protecting and insulating FTA members from global competition. Similarly, the use of anti-dumping and countervailing measures at the regional level may also shelter regional industries from the global market. ${ }^{119}$ Furthermore, FTAs tend to avoid hard

113 See Daniel W. Drezner, 'On the Balance between International Law and Democratic Sovereignty', 2 Chi. J. Int'l L. (2001) 321, 329. Though Kindleberger once maintained that the US supported the multilateral trading system as established in the GATT 1947 after the Second World War as a 'public good', the US has now been in the 'diminished giant syndrome' where it is eager to take care of its own interest. See Jagdish Bhagwati and Douglas A. Irwin, 'The Return of the Reciprocitarians: US Trade Policy Today', 10 World Econ. (1987) 109. See also Anne O. Krueger, American Trade Policy: A Tragedy in the Making (1995) 7 (observing that the current US shift to bilateralism is an outcome of gradual erosion of the commitment to multilateralism).

${ }^{114}$ See e.g., Rudiger W. Dornbusch, 'Policy Options for Freer Trade: The Case for Bilateralism', in Robert Z. Lawrence and Charles L. Schultze (eds), An American Trade Strategy: Options for the 1990s (Washington, DC: Brookings Institution, 1990) 106-141 (arguing that a trade bloc could render a fresh boost to freer trade); Fred Bergsten, 'A Competitive Approach to Free Trade', Financial Times (5 December 2002), at 13 (making a case of 'competitive liberalization'). However, in the area of regulatory cooperation and harmonization regionalism may play a constructive and complementary role vis-ä-vis multilateralism. See Sungjoon Cho, 'Breaking the Barrier between Regionalism and Multilateralism: A New Perspective on Trade Regionalism', 42 Harv. Int'l L. J. (2001) 419, 42936.

115 C. Fred Bergsten, 'Open Regionalism', 20 World Econ. (1997) 545, 548.

116 John H. Jackson, 'Regional Trade Blocs and the GATT', 16 World Econ. (1993) 121, 130; Harold Hongju Koh, 'The Legal Markets of International Trade: A Perspective on the Proposed United States - Canada Free Trade Agreement', 12 Yale J. Int'l L. (1987) 193, 248. But see Michael P. Malloy, 'Bumper Cars: Themes of Convergence in International Regulation', 60 Fordham L. Rev. (1992) s 1, s 21-22 (describing a potential danger of regulatory clash between different jurisdictions using a 'bumper car' model).

117 See Stephen Woolcock, 'Regional Integration and the Multilateral Trading System', in Till Geiger and Dennis Kennedy (eds), Regional Trade Blocs, Multilateralism, and the GATT: Complementary Paths to Free Trade (London: Pinter, 1996) 116; David Henderson, 'The EC, the US and Others in a Changing World Economy', 16 World Econ. (1993) 537, 538.

118 Bhagwati, above n 111, at 290.

119 See e.g., L. Alan Winters, 'The EC and Protection: The Political Economy', 38 Eur. Econ. Rev. (1994) 596. 
issues such as agriculture and anti-dumping. This tendency has been reconfirmed in the recent FTAA debates between Brazil and the US. The US is reluctant to include agriculture and anti-dumping, which are politically combustible issues, in the FTAA talk and wants them to be addressed under the Doha Round, while Brazil prioritizes them as the core agendas of the FTAA. $^{120}$

Bilateral deals also may result in a negative effect even among non-US partners. The US, as a 'hub', enjoys free access to these 'spokes' and holds a superior position even in its domestic market due to economies of scale. However, these spokes cannot collectively share benefits of improved market access from each bilateral deal unless they form a 'rim' among themselves by signing similar deals with one another. ${ }^{121}$

Nonetheless, the sum of all fears would be the surfacing of 'unilateralism'. The inherent discriminatory nature of bilateralism/regionalism is often blended with an internal power disparity and ultimately begets unilateralism. Unilateralism, which is often clad with extraterritoriality, tends to eclipse international trade law, thereby placing the global trading system at the mercy of bare politics by a handful of powerful states. This would be an anathema to the WTO's telos - 'an integrated, more viable and durable multilateral trading system'. 122

\section{Is a deal still possible?}

Although the Cancún Ministerial Declaration mandated a General Council meeting at the senior officials' level no later than 15 December $2003,{ }^{123}$ very few people would believe that the negotiation will be sealed until the original deadline, 1 January 2005 , which itself is very close at hand. ${ }^{124}$ To make things worse, 2004 is rife with important elections in major countries, including the US presidential election. In the face of these elections, it would be very difficult to expect politicians to speak out for the cause of international trade at the risk of sacrificing local constituencies. In fact, local protectionism seems to have already sprung up as a reaction to the fall of the Cancún Conference. $^{125}$

If Member countries are willing to extend the original deadline however, which they will probably do, a deal is not out of the question. Some

\footnotetext{
120 See 'Trade in the Americas: Much Wind and Little Light', The Economist (18 October 2003), at 3536.

121 See Frank J. Garcia, 'NAFTA and the Creation of the FTAA: A Critique of Piecemeal Accession', 35 Va. J. Int'l L. (1995) 539, 558.

122 WTO Agreement, above n 3, preamble.

123 The Cancún Statement, above n 84.

124 Bridges, Issue 6, above n 74.

125 See 'Protectionist Pressure Building Up', above n 112; Edward Alden et al.', Recriminations Fly after Failure of WTO Talks', Financial Times (15 September 2003), www.ft.com.
} 
explanation supports this cautious optimism. First, micro-level developments in Cancún, in particular during the final two days, exhibited the softening of some Member countries' positions. For example, the EU was reportedly prepared to drop investment and competition out of the Doha Round at the last moment. ${ }^{126}$ It should also be remembered that individual positions within each representative coalition are not homogeneous, which tends to make their future coalitions porous and leaves room for shifting positions. As mentioned above, an internal conflict of interest may exist within the G-21, especially between India and Brazil. Furthermore, developing countries may not stand as one group considering different inner voices from G-21, such as G-33 and AU/ACP/LDCs. Even the EU member states were not united internally on the Singapore issues, in particular over when and how to launch them. ${ }^{127}$

Third, despite protectionist sentiment due to major domestic elections, a couple of political forces may counteract such sentiments. Many influential international organizations (IOs), such as the IMF and the World Bank, as well as non-governmental organizations (NGOs), expressed their strong support for developing countries' demands in Cancún. Their continuing support is likely to have a ripple effect even in the domestic political realm. Also, the business community is eager to boost languishing economies by launching a new round. They will certainly lobby their governments to do something to revive the momentum of negotiations. ${ }^{128}$ These factors have led the Asia Pacific Economic Cooperation (APEC) ministers to voice their support for the restart of the Doha round talks, urging WTO Members to show 'flexibility and political will' to achieve an 'ambitious and balanced outcome'. ${ }^{129}$ Last, but not least, under most circumstances politicians prefer to declare 'success' than 'failure', even if the final package is not fully satisfactory. ${ }^{130}$

While these factors create a positive atmosphere for a future trade deal in the Doha Round, other efforts should also be added to facilitate actual negotiations. First, the role of the WTO Secretariat is critical. As discussed above, at the micro-level there are possibilities of progress in the negotiations through further consultation, clarification, and concession against the backdrop of the Cancún coalitions, most of which are still fluid in nature. In fact, a host of good suggestions on both the modalities and substance of the negotiations were spelled out in Cancún. At this juncture, the critical mission

\footnotetext{
126 Bridges, Issue 6, above n 74.

127 Bridges, Issue 4, above n 104.

128 International Chamber of Commerce (ICC), Businesses Large and Small Launch Campaign to Push for Renewed WTO Talks, http:/www.iccwbo.org/home/news_archives/2003/stories/chambers_wto.asp.

129 Joint Statement, 15th APEC Ministerial Meeting, Bangkok, 18 October 2003, http://www.apecsec.org.sg/content/apec/ministerial_statements/annual_ministerial/2003_15th_apec_ministerial.html.

130 See Hufbauer, Foote Lecture, above n 94.
} 
of the WTO Secretariat is to scrutinize these possibilities and suggestions, and furnish a rich set of workable alternatives that comprises various matrices of give-and-take across major topics, such as farm subsidies and the Singapore issues. For instance, one can conceive a scenario under which developed countries commit to phase out all export subsidies to products of particular interests to LDCs and substantially reduce those subsidies to listed products of particular interests to other developing countries, ${ }^{131}$ while developing countries agree to launch the negotiations of the Singapore issues on a selective basis, i.e., excluding investment and competition. Member countries may use this set of scenarios, which may be labeled the 'Supachai text', as a basis of future negotiations. This approach may save the Doha Round just as the 'Dunkel text' saved the Uruguay Round a decade ago.

Additionally, Members should devise a more effective and efficient decision-making mechanism. With nearly 150 Members now, it becomes harder for the WTO to deliver any important decision within a reasonable period of time. This is not to advocate any grand, constitutional change, such as simple majority voting, but rather to expect some sort of administrative breakthrough. Although the current system of using 'friends of the chair' or 'facilitators' tends to overcome, to some extent, the titular 'green room' predicament, the WTO needs to adopt an institutional change. As DirectorGeneral Supachai once proposed by referring to the Development Committee and the Interim Committee (now the International Monetary and Financial Committee) in the World Bank and the International Monetary Fund, ${ }^{132}$ some sort of 'intermediate committee' that aims to smooth the progress of intergovernmental consensus-making might be an option to achieve such institutional reform.

\section{CONCLUSION: TOWARD ANOTHER CONSTITUTIONAL MOMENT}

While it is true that globalization and trade expansion have benefited many people in the world, poverty still lingers in many corners of the globe, and, in many cases, is becoming worse. ${ }^{133}$ A strong consensus is beginning to emerge that the global community can no longer sustain the current level of poverty

131 From a similar perspective, Jeffrey Schott argues that the US should play a leading role in 'reengaging the agricultural negotiations' with a view to agreements on substantial reduction of domestic and export farm subsidies and special measures to help least-developed cotton-exporting countries. Jeffrey Schott, 'Unlocking the Benefits of World Trade', The Economist (1 November 2003), at 67.

132 See Supachai, above n 19, at 437.

133 See United Nation Millennium Declaration, A/res/55/2, para 5, 18 September 2000, http:// www.un.org/millennium/declaration/ares552e.pdf ('For while globalization offers great opportunities, at present its benefits are very unevenly shared, while its costs are unevenly distributed'.). 
and economic inequality. ${ }^{134}$ It seems simply unacceptable that rich countries' annual sum of agricultural subsidies has become 'enough to fly 41 million dairy cows first class around the world one and a half times', ${ }^{135}$ while countless farmers in poor countries suffer from a continued suppression in their produce's price due to these subsidies. ${ }^{136}$ Poverty is no longer a mere issue of economic policy: It is a 'matter of life and death' ${ }^{137}$ to many people now inhabiting the earth. ${ }^{138}$ In this regard, the fall of the Fifth WTO Ministerial Conference in Cancún seemed to have made at least one contribution: It spotlighted the development crisis that the global community is now suffering.

As Amartya Sen eloquently observes, this unsustainable economic inequality will become less tolerable as the global trading community becomes more integrated and interdependent. ${ }^{139}$ Beyond the rhetoric of unfairness and injustice, this 'global apartheid" ${ }^{140}$ is a clear and present danger, here and now. 'Poverty anywhere constitutes a danger to prosperity everywhere'. ${ }^{141}$ That is, underdevelopment and marginalization at one corner can and do lead to asymmetrical shocks or direct physical threats to another. ${ }^{142}$ If we truly want to live peacefully together, it is imperative that we deliver development

134 See WTO: Trade Body Protests 'Nightmare' Reports, UN Wire, 25 August 2000, http:// www.unwire.org/unwire/20000825/current.asp; UN Trade Conference Calls for 'Fairer' Economic System, CNN.com, 18 February 2000, www.cnn.com/2000/ASIANOW/southeast/02/18/world.trade.02/index.html; 'White Man's Shame', The Economist (24 September 1999), www.economist.com: G-77: Poor Countries Call for Fair Trade, UN Wire, 17 Apr. 2000, http://www.unwire.org/ unwire/20000417/current.asp; WTO: UN Report Charges Bias against Poorer Nations, UN Wire, 14 August 2000, http://www.unwire.org/unwire/20000814/current.asp; Little Improvement for World's Poor in 1990s - World Bank, UN Wire, 4 August 2000, http://www.unwire.org/unwire/20000804/ current.asp.

135 WTO, The 10 Benefits of the WTO Trading System: 4. Cost of Living, http://www.wto.org/english/ thewto_e/whatis_e/10ben_e/10b04_e.htm.

136 See John Kanjagaile, 'Cancun Should Cultivate Fairness', 10 September 2003, Financial Times, www.ft.com.

137 See WTO, Press Release, Speech by the Director-General Mike Moore, National Conference on the Millennium Round (Rome, 11 November 1999), http://www.wto.org/english/news_e/spmm_e/ spmm14_e.htm.

138 See e.g., Charlotte Denny, 'US Blocks Brown-led Drive for Increase in Aid', Guardian Unlimited, 23 Jan. 2002, http://www.guardian.co.uk/business/story/0,3604,637808,00.html (reporting that 2.8 billion people on earth live on less than $\$ 2$ a day).

139 Amartya Sen, 'Global Doubts', Harv. Mag. 68 (September-October 2000).

140 See Joel Trachtman, 'Legal Aspects of a Poverty Agenda at the WTO: Trade Law and 'Global Apartheid,' 6 JIEL (2003) 3-21.

141 The Constitution of the International Labor Organization, Annex (Declaration Concerning the Aims and Purposes of the International Labor Organization), para I (c), http://www.ilo.org/public/ english/about/iloconst.htm\#annex.

142 See Poverty: U.K. Chancellor Calls for New Marshall Plan for the Developing States, UN Wire, 18 December 2001, http://www.unwire.org/UNWire/20011218/22676_story.asp (quoting Gordon Brown, UK Chancellor of the Exchequer, who linked 'poverty in the developing world' to 'direct physical threats to people in industrialized countries'). 
to every corner of the world. This is best accomplished through trade, with its uniquely demonstrated ability to promote welfare and prevent warfare.

However, to fulfill this development goal under the global trading system the WTO need not, and should not, be converted into a 'donor's conference'. ${ }^{143}$ Truly, the WTO is traditionally a venue for trade negotiations, which inevitably involves quid pro quo and sometimes tit-for-tat. Nevertheless, this reciprocity should be put in perspective considering current dire situations in some corners of the globe where benefits of globalization and free trade have been bestowed disproportionately vis-à-vis other regions. To avoid the marginalization of these least-developed countries and help them integrate their economies into the global stream, more liberal market access must be granted in the areas where these countries hold comparative advantage, such as agriculture and textiles.

The bottom line is that being a trading partner is remarkably superior in aiding their development than being a mere donee. Such enhanced market access should come from both developed and developing, in particular 'middle-income' developing, countries. At this juncture, developing countries should realize that protection in any form, including non-reciprocal, preferential treatment, has only a limited, temporary effect for their development. Yet, at the same time developed countries should also realize that not every country could and should propose the same magnitude of trade liberalization as the developed countries themselves might and should do. ${ }^{144}$

In conclusion, we do not need nor want a deus ex machina of World Government to overcome the current development crisis. The solution is clear. All agree that we have to return to the basic tenet of trade liberalization: lowering and eventually eliminating tariffs and non-tariff barriers as well as repealing market-distorting practices such as subsidies. We also agree that the capacity of some of our esteemed trading partners should be firmly built through the redistributive mechanism of financial and technical assistance from better-off trading partners so that the former can truly integrate themselves to the global enterprise of trade. What is lacking is bold 'leadership' on domestic fronts that can transcend local parochialism and redefine a national interest by taking into account other nations' interest, ${ }^{145}$

143 I thank an anonymous commentator on an earlier draft of this article for raising this important issue.

144 See Edward Alden, 'US Farmers Issue Cancun Warning', Financial Times (8 September 2003), www.ft.com. Alden reported that: 'US negotiators are fighting to enshrine the concept of 'harmonization', which would require countries with higher tariffs and greater subsidies to eliminate those barriers much more rapidly than countries with fewer distortions. That would mean Europe and Japan would cut subsidies much more than the US, while developing countries would face even steeper tariff cuts.'

145 Joseph S. Nye Jr., The Paradox of American Power: Why the World's Only Superpower Can't Go It Alone (Oxford: Oxford University Press, 2002) 138. 
and eventually materialize a grand vision of common prosperity, peace and human dignity. ${ }^{146}$

The global trading system has thus far undergone two constitutional moments: the birth of GATT 1947 and the birth of the WTO. Inspiringly, both moments sprang up as desperate responses to daunting challenges of the time. Although we still suffer from the aftermath of Cancún, we must embrace another constitutional moment, successfully complete the Doha Round, and breathe new life and meaning into our Trade Constitution and its telos of an 'integrated, more viable and durable multilateral trading system'.

146 Cf. Immanuel Kant, 'Perpetual Peace: A Philosophical Sketch' (1795), in Hans Reiss (ed), H.B. Nisbet (trans), Kant's Political Writings, 2nd ed. (New York: Cambridge University Press, 1991) 93, 114. 